\title{
MALE INFERTILITY IN LIBYAN ARAB JAMAHIRIYA
}

\author{
M.G. Muazzam*
}

\begin{abstract}
Male infertility is also an important social problem. 160 male subjects were examined in Libya. $90.00 \%$ subjects were between the age of 20-30 years. Ou if 160 male $60(37.50 \%)$ were normospermic. $60(37.53 \%)$ oligospermic , 28 $(17.50 \%)$ azoospermic and $12(7.50 \%)$ were Necrospermic. So $63.50 \%$ subjects had fertility problem.
\end{abstract}

\section{Introduction}

Due to over emphasis on the necessity of population control in recent times, infertility is often neglected in many developing countries. In the densely populated areas of Asia, Africa and Latin America, most of the Governments are concerned to the problem of over population to such an extent that, in those countries 'Family Planning' has become almost synonymous with 'Birth Control'. But infertility is always a social and personal problem in all countries, rich or poor. The failure to procreate is not less painful for the infertile couple than the problem of too many children in a poor family. However, in the developed countries whereover population is not a problem, infertility still remains an important social and medical problem. Again in some developing but very rich countries like oil-rich Libya, where population is too small for its vast land and natural resources, infertility is one of the major medical problem. In Tripoli, the capital of Libya, infertility cases represent $31.48 \%$ of all cases of endometrial biopsies (Muazzam and Elkassaby, 1983).

In Libya married couples expect children within one year of marriage. During my stay in that country I had the opportunity to investigate both male and female subjects seperately for primary inferitility. No such report has so far been published from Libya. The present paper deals with the semen analyses of male infertile subjects in Libya.

* Prof. M.G Muazzam. MBBS (cal), DCP (Lond). D.Path (Eng), FCPS (BD), FRC Path (Eng). Ex-Consultant Pathologist in Libya djuring 1975-77 and Prof. of Patholgy. AL-Fateh Univ. Tripoli, Libya, during 1979-82. 


\begin{tabular}{lcccrrr}
\hline Age-group & $\begin{array}{r}\text { Normo- } \\
\text { spermic }\end{array}$ & $\begin{array}{r}\text { Oligo- } \\
\text { spermic }\end{array}$ & $\begin{array}{r}\text { Necro- } \\
\text { spermic }\end{array}$ & $\begin{array}{r}\text { Azoo- } \\
\text { spermic }\end{array}$ & Total & Percentage \\
\hline 19 years & 1 & 1 & 1 & - & 3 & 1.85 \\
$20-25$ yrs. & 32 & 37 & 6 & 17 & 92 & 57.50 \\
$26-30$ yrs. & 22 & 19 & 5 & 6 & 52 & 32.50 \\
$31-35$ yrs & 2 & 3 & - & 3 & 8 & 5.00 \\
$36-40$ yrs. & 1 & - & - & 1 & 2 & 1.25 \\
$41-45$ yrs. & 1 & - & - & 1 & 2 & 1.25 \\
46 years & 1 & - & - & - & 1 & 0.65 \\
\hline Total & 60 & 60 & 12 & 28 & 160 & 100.00
\end{tabular}

Tablel-1. Age-distribution.

\begin{tabular}{lrrrrrr}
\hline $\begin{array}{l}\text { Volume } \\
\text { in ML. }\end{array}$ & $\begin{array}{r}\text { Normo- } \\
\text { spermic }\end{array}$ & $\begin{array}{r}\text { Oligo- } \\
\text { spermic }\end{array}$ & $\begin{array}{r}\text { Necro- } \\
\text { spermic }\end{array}$ & $\begin{array}{r}\text { Azoo- } \\
\text { spermic }\end{array}$ & Total & Percentage \\
\hline Less than 1.0 ml. & - & 7 & 3 & 5 & 15 & 9.37 \\
$1-2.0 \mathrm{ml}$. & 18 & 20 & 3 & 8 & 49 & 30.62 \\
$2.1-3.0 \mathrm{ml}$. & 23 & 17 & - & 5 & 45 & 28.12 \\
$3.1-4.0 \mathrm{ml}$. & 8 & 10 & 3 & 5 & 26 & 16.25 \\
$4.1-5.0 \mathrm{ml}$. & 8 & 4 & - & 2 & 14 & 8.75 \\
$5.1-6.0 \mathrm{ml}$. & 2 & 1 & 2 & - & 5 & 3.12 \\
$6.1-7.0 \mathrm{ml}$. & - & - & 1 & - & 1 & 0.63 \\
$7.1-8.0 \mathrm{ml}$. & - & 1 & - & 2 & 3 & 1.89 \\
$8.1-8.6 \mathrm{ml}$. & 1 & - & - & 1 & 2 & 1.25 \\
\hline Total & 60 & 60 & 12 & 28 & 160 & 100.00
\end{tabular}

Table-2. Volume of semen specimens.

\section{Materials and Methods}

Semen analysis was done of 160 male subjects referred for the investigation of primary sterility. The examinations were done in the UQBA-bin-Naafe army hospital laboratory in Tripoli during 1975-76. The Seminal specimens were produced by the patients in the laboratory by masterbation; colour, viscosity and reactions and motility were noted and the specimen was allowed to liquify at room temperature. After about $\frac{1}{2}$ to 1 hour. sperm count per ml was done by haemocytometer. Morphology was studied, and the total volume measured. In cases where analysis was repeated, the average was taken as one examination. Morphology and motility were studied by eye estimation in thin covership preparations. The presence of abnormal cell if present was also noted. 


\section{Results}

Table 1 shows the age distribution of the subjects, $90.00 \%$ (144) patients belonged to the age-group of 20-30 years.

Table 2 shows the volume of seminal fluids. 9.37\% (15) specimens had a volume less than $1.0 \mathrm{ml}$ and $83.75 \%$ (134) had volume of $1.0-5.0 \mathrm{ml}$., the range of volume being $0.25 \mathrm{ml}-8.6 \mathrm{ml}$.

Table 3 shows the number of sperms per $\mathrm{ml}$, the range being 0.001 mllion to 300 million. $61.36 \%$ (81) specimens had a sperm count below 50 million per ml., while $38.64 \%$ (51) had normal count of 50-300 million per ml. 28 (17.50) specimens were Azoospermic (Tablel).

\begin{tabular}{lccccc}
\hline $\begin{array}{l}\text { Number of } \\
\text { sperms per ml. }\end{array}$ & $\begin{array}{c}\text { Normo } \\
\text { permic }\end{array}$ & $\begin{array}{c}\text { Oligo } \\
\text { spermic }\end{array}$ & $\begin{array}{c}\text { Necro } \\
\text { spermic }\end{array}$ & Total & Percentage \\
\hline Less than 1.0 million & - & 22 & 10 & 32 & 24.24 \\
10-20 Million & - & 14 & 2 & 16 & 12.12 \\
21-49 Million & 12 & 21 & - & 33 & 25.00 \\
50-100 Million & 22 & 2 & - & 24 & 18.18 \\
101-150 Million & 11 & 1 & - & 12 & 9.10 \\
151-200 Million & 8 & - & - & 8 & 6.06 \\
201-250 Million & 4 & - & - & 4 & 3.03 \\
$251-300$ Million & 3 & - & - & 3 & 2.27 \\
\hline Total & 60 & 60 & 12 & 132 & 100.00
\end{tabular}

Table -3. Number of sperms per $\mathrm{ml}$. in 132 specimens.

Table 4 (a) shows the number of sperms per ejaculate. Among 132 spermic subjects, $37.88 \%(50)$ subjects had less than 50 million sperms per ejaculate.

Table 4 (b) shows the total number of active sperms per ejaculate. 72 (72) had less than 50 million active sperms per ejaculate.

Table 5 shows the types of semen found in this study taking 50 million normal active sperms per ejaculate as the minimum lower limit for normospermia. $37.50 \%(60)$ specimens were normospermic.

Table 6 (a) \& (b) show the percentage of motility and morphologically normal sperms respectifvely in the three categories in which sperms were present.

Table 7 shows the viscosity and colour of the specimens.

Table 8 shows the duration of sterlity. 


\section{Discussion}

Age - $144(90.0 \%)$ subjects belonged to the usual age of marriage - 20 to 30 years. Only $3(1.88 \%)$ were 19 years old and the remaining $13(8.12 \%)$ were between 31-46 years. (Table 1). In a similar study in Bangladesh, most of the subjects were between $30-40$ years, the range being $25-50$ years (Muazzam, 1965). It further shows that in Libya. infertile males go for investigation relatively earlier than those in Bangladesh. It also reflects that the Libyan males marry relatively earlier and expect children soon after marriage. (Table-8)

Volume of Semen - Different workers have given different range of volume as the normal limit. Clayton et al. (1980) reported an average volume of $3.4 \mathrm{ml}$. with a range of 0.2-6.6 ml. Nelson and Beng (1974) gave a range of $1-7 \mathrm{ml}$ with an average of $2.83 \mathrm{ml}$. while Harrison and de-Boer (1977) reported 2-7 ml. with an average of $3.5 \mathrm{ml}$.

\begin{tabular}{lcc}
\hline $\begin{array}{l}\text { Number of } \\
\text { sperms per } \\
\text { ejaculate }\end{array}$ & $\begin{array}{c}\text { Number of } \\
\text { specimens }\end{array}$ & Percentage \\
\hline Less than 1.0 million & 11 & 8.33 \\
$1.0 \mathrm{~m}-9.9$ Million & 15 & 11.37 \\
$10.0 \mathrm{~m}-49.9$ Million & 24 & 18.18 \\
$50 \mathrm{~m}-100$ Million & 20 & 15.15 \\
$101 \mathrm{~m}-200$ Million & 34 & 25.76 \\
$201 \mathrm{~m}-300$ Million & 21 & 15.91 \\
$301 \mathrm{~m}-400$ Million & .7 & 5.30 \\
\hline Total & 132 & 100.00
\end{tabular}

Table-4 (a). Number of sperms per ejaculate.

\begin{tabular}{lcc}
\hline $\begin{array}{l}\text { Number of } \\
\text { Active sperms } \\
\text { perejaculate }\end{array}$ & $\begin{array}{l}\text { Number of } \\
\text { specimens }\end{array}$ & Percentage \\
\hline Less than 1.0 million & 18 & 13.64 \\
$1.0-9.9$ million & 20 & 15.15 \\
$10.0-49.9$ mill. & 34 & 25.76 \\
$50.0-100 \mathrm{mill}$. & 17 & 12.88 \\
$101.0-200 \mathrm{mll}$. & 21 & 15.91 \\
$201 \mathrm{~m}-300 \mathrm{mill}$. & 14 & 10.60 \\
$301 \mathrm{~m}-400 \mathrm{mill}$. & 8 & 6.06 \\
\hline Total & 132 & 100.00
\end{tabular}

Table-4(b). Active Sperms per ejaculate. 
Copenhaver et al. (1971 reported a range of 2-6 ml. while Hudson et al. (1980) gave $1-4 \mathrm{ml}$ as normal volume for $80 \%$ fertile men.

The present study shows a range of 1.5 to $7.0 \mathrm{ml}$. for the normospermic specimens with an average of $2.83 \mathrm{ml}$., which is similar to the figures of Nelson and Beng. In a similar study in Bangladesh (Muazzam, 1962) the volume of semen of normospermic subjects were $1.5-6.0 \mathrm{ml}$., which is comparable to the figures obtained in Libya.

The range of volume in the present series, including the abnormal specimens is $0.25 \mathrm{ml} .8 .6 \mathrm{ml}$. and $9.37 \%$ (15) had a volume less than $1.0 \mathrm{ml}$. (Table 2)

Sperm Count - Many workers have reported sperm count per $\mathrm{ml}$ of semen and the percentage of motility and morphologically normal sperms as criteria of fecundity. The number of sperms per $\mathrm{ml}$. varies from 50-300 million in average normal subjects. Clayton et al (1980) gave a range of 60-250 million, Nelson and Beng (1974) 48 million, while Americal Fertility society (1971) regard 40 million per $\mathrm{ml}$. as the lower limit. In a previous study in Bangladesh (Muazzam, 1962) 50160 million per $\mathrm{ml}$. was found among the normospermic specimens. In the present series the sperm count varied from 0.001 million-300 mill. per ml. 81 $(61.36 \%)$ specimens out of 132 had a sperm count below 50 million/ml while 51 (38.64\%) had normal count. Though the normospermic specimens showed a count of 24-300 million $/ \mathrm{ml}$ with an average of $111.6 \mathrm{million} / \mathrm{ml}$. (Table 3).

But the number per $\mathrm{ml}$ is of less importance than the total number of sperms per ejaculate. A very high count in a very small volume has less chance of fecundity. So, only per ml. concentration should not be accepted as a criteria of fecundity. Again the total number is of no significance unless they are morphologically normal and actively motile. So, number of active sperms per ejaculate in a reasonable volume (not less than $1.0 \mathrm{ml}$ ) is of real significance (Muazzam, 1965). Farris (1950) and Hudson et el. (1980) accept 50 million per ejaculate as the lower limit of normal semen but they do not specify the number of living and morphologically normal sperms in the ejaculate. MacLeod and Gold (1953) reported that fertility was possible with 20 million sperms per $\mathrm{ml}$. I have got a personal information about one person suffering from generalised leprosy from childhood, whose sperm count was 20 mill per ml. but total active sperm were 50 mill per ejaculate, proved himself fertile. On this ground 50 million active sperm per ejaculate in a volume not less than $1.0 \mathrm{ml}$ has been taken as the lower limit of normospermia (Muazzam,1965), In the present series total number of sperms per ejaculate varied from less than 1.0 million to 700 million, and number of actlve sperms varied from none to 400 million (Table 4 (a) and 4 (b). Types of semen - The seminal specimens were divided into 4 types as follows : (Table 5)

(a) Normospermic - taking 50 million living normal sperms per ejaculate as the lowest limit of normospermia (Normal semen). $37.50 \%(60)$ specimens were normospermic in this series. This is comparable to $38.50 \%(50)$ found in Bangladesh (Muazzam, 1965). 
Types of semen

Normospermic

Oligospermic

Necrospermic

Azoospermic

Total

Table-5. Types of semen taking 50 million sperms per ejaculation as the lowest limit for normospermia.
Percenatage

specimens
60

60

12

28

160
37.50

37.50

7.50

17.50

(b) Oligo spermic - Specimens showing less than 50 million living normal sperms per ejaculate. $37.50 \%(60)$ specimens belonged to this group. This, is much higher than 20\% (26) found in Bangladesh (Muazzam. 1965).

(c) Necrospermic - specimens showing maximum number of deformed sperms are considered as Necrospermia. $7.50 \%$ (12) specimens belonged to this group. This is also higher than $4.6 \%$ (6) necrospermia found in Bangladesh (Muazzam, 1965). All the necrospermic specimens were oligospermic as well.

(d) Azoospermic - Total absence of any spermatozoon in a specimen is called Azoospermia. In this series $17.50 \%$ (28) specimens were azoospermic which is almost half of $36.9 \%$ (48) found in Bangladesh (Muazzam, 1965).

Thus the non-fecundating specimens in the series is $62.50 \%$ which is comparable to $61.50 \%$ found in Bangldesh. But so far the abnormal specimens are concerned, both oligospermia and necrospermia are higher among the Libyans than among the Bangladeshis. Azoospermia on the otherhand is almost double among the Bangladeshis than among the Libyan subjects.

The reason of such high incidence of azoospermia among the Bangladeshi subjects is not clear. To assess this interesting finding semen analysis of normal young adults of both the countries should be done to find out the normal rate of azoospermia in the two nations.

Morphology of the sperms - In the present series $65.91 \%(87)$ specimens $(87$ out of 132) showed 51-90\% normal morphology. Among the normospermic specimens $93.33 \%$ (53 out of 60 ) specimens showed $51-90 \%$ normal morphology (Table 6(b). 
Percentage Normospermic Oligospermic Necrospermic Total Remarks Normal

\begin{tabular}{lrrrr}
\hline None & - & - & 2 & 2 \\
$1-10 \%$ & - & - & 6 & 6 \\
$11-20 \%$ & - & 4 & 1 & 5 \\
$21-30 \%$ & - & 7 & 1 & 8 \\
$31-40 \%$ & 2 & 12 & - & 14 \\
$41-50 \%$ & 5 & 9 & 1 & 15 \\
$51-60 \%$ & 12 & 11 & 1 & 24 \\
$61-70 \%$ & 16 & 9 & - & 25 \\
$71-80 \%$ & 17 & 6 & - & 23 \\
$81-90 \%$ & 6 & 2 & - & 8 \\
$91-100 \%$ & 2 & - & - & 2 \\
\hline Total & 60 & 60 & 12 & 132
\end{tabular}

Table 6(a) Motility of the sperms

Macleod and Gold (1951) reported more than $60 \%$ normal sperms in $90 \%$ and more than $70 \%$ in $80 \%$ normal semen.

Among the Oligospermic specimens only $50 \%$ (30 out of 60 ) showed $51-80 \%$ normal morphology. In the necrospermic group only one showed $55 \%$ normal morphologh. (Table 6(b)

Motility of sperms - In the series $45 \%$ (72) showed $51-80 \%$ motility, though $75 \%$ (45) of normospermic specimens showed $51-80 \%$ motility. $40.33 \%$ (26) oligosperinic and $8.33 \%$ (1 out of 12) Necrospermic specimens showed $51-80 \%$ motility (Table 6(a). Hudson etal (1980) take $40 \%$ motility as an evidence of abnormal semen.

Viscosity - $91.70 \%$ (55) normospermic, $66.7 \%$ (40) oligospermic, $50 \%(6)$ necrospermic and $28.6 \%(8)$ azoospermic specimens were of normal viscosity. $64.3 \%$ (18) azoospermic specimens showed viscosity less than normal. A small number of all the types of semen showed higher viscosity. So less viscosity is more compatible with abnormal semen. (Table 7)

Colour $-91.7 \%$ to $93.3 \%$ specimens of all categories of semen except necrospermix had normal colour. So colour is of little significance to indicate abnormality of semen. (Table 7).

From the above discussion it is evident that $25 \%(40)$ subjects in this series had definite cause of sterility in the form of azoospermia and necrospermia. From a study of endometrial biopsies of the primary sterlity cases in Libya $25.29 \%$ (170 to out of 700) showed definite causes of sterility in the form of non-secretory endometrium and endometrial hyperplasia (Muazzam and Elkassaby, 1983). So it seems that in primary sterility among the libyans, male and female partners are equally responsible in $50 \%$ cases. The remaining $50 \%$ may be due to defects in both of them. But the present study shows that only $37.50 \%$ male subjects produced normal semen and the remaining $62.50 \%$ had some abnormality. 
Similarly in the study among females (1983) $55.14 \%$ (386 out of 700 ) women showed normal functioning endometrium while the remaining $44.86 \%$ had some sort of abnormalities. So in case of primary sterility, male partners should first be investgated as it is simple and higher percentage of males are found defective. If the semen analysis is found normal, then the female should be thoroughly investigated.

\begin{tabular}{lccccc}
\hline $\begin{array}{l}\text { Percentage } \\
\text { Normal }\end{array}$ & $\begin{array}{c}\text { Normo- } \\
\text { spermic }\end{array}$ & $\begin{array}{c}\text { Oligo- } \\
\text { spermic }\end{array}$ & $\begin{array}{r}\text { Necro- } \\
\text { spermic }\end{array}$ & Total & Remarks \\
\hline None & - & - & 1 & 1 \\
$1-10 \%$ & - & - & 6 & 6 & \\
$11-20 \%$ & - & 1 & - & 1 & 4 \\
$21-30 \%$ & - & 4 & - & 13 \\
$31-40 \%$ & - & 10 & 3 & 20 \\
$41-50 \%$ & 4 & 15 & 1 & 32 \\
$51-60 \%$ & 18 & 13 & 1 & 30 \\
$61-70 \%$ & 18 & 12 & - & 22 \\
$71-80 \%$ & 17 & 5 & - & 3 \\
$81-90 \%$ & 3 & - & - & - \\
$91-100 \%$ & - & - & - & 132 \\
\hline Total & 60 & 60 & 12 &
\end{tabular}

Table-6(b). Morphology of the sperms.

Duration of sterility - $5.63 \%$ (9) came for investigation within one year and $11.25 \%$ (18) came after one year of marriage. $46.87 \%$ (75) reported for investingation withing 2 years, Though $86.26 \%$ (138) came within 5 years of marriage. $12.5 \%(20)$ reported for investigation after 5-15 years of marriage and only $1.25 \%$ (2) came between 16 to 25 years of marriage. (Table 8)

Usually married couples with good health and ample opportunity for copulation for two years, if fail to conceive, they should submit themselves for investigation of primary sterility. From the present study it is evident that in the rich but underpopulated country like Libya, people are eager to get children soon after marriage. 


\begin{tabular}{lrrrrrrrrr}
\hline & $\begin{array}{c}\text { Normo- } \\
\text { spermic }\end{array}$ & $\begin{array}{c}\text { Per- } \\
\text { centage spermic }\end{array}$ & $\begin{array}{c}\text { Oligo- } \\
\text { spermic }\end{array}$ & $\begin{array}{r}\text { Azoo- } \\
\text { spermic }\end{array}$ & $\%$ \\
\hline A. Colour : & & & & & & & & & \\
Normal & 56 & 93.4 & 55 & 91.7 & 6 & 50.0 & 26 & 92.9 \\
White & 2 & 3.3 & 5 & 8.3 & 4 & 33.3 & 2 & 7.1 \\
Yellow & 2 & 3.3 & - & - & 2 & 16.7 & - & - \\
Total & 60 & 100.0 & 60 & 100.0 & 12 & 100.0 & 28 & 100.0 \\
B. Viscolity : & & & & & & & & \\
Normal & 55 & 91.7 & 40 & 66.7 & 6 & 50.0 & 8 & 28.6 \\
Less & 1 & 1.6 & 13 & 21.7 & 5 & 41.7 & 18 & 64.3 \\
High & 4 & 6.7 & 7 & 11.6 & 1 & 8.3 & 2 & 7.1 \\
\hline Total & 60 & 100.0 & 60 & 100.0 & 12 & 100.0 & 28 & 100.0
\end{tabular}

Table-7. Colour and viscosity of the semen.

In a similar study in Bangladesh in two series, only $10.0 \%$ (Muazzam, 1965) and $12.50 \%$ Muazzam, 1962) subjects came for investigation within 5 years of marriage) while $80 \%$ to $85 \%$ came after 5 to 20 years of marriage.

Polygamy - Though polygamy is allowed in Islamic society under certain. circumstances, and sterlity is one such situation, it is interesting to note that only $10.0 \%$ (16) sbubjects in this series married a second wife (and none more than one) before they came for investigation. One of them, however divorced his wife before second marriage. The period between first and second marriage ranged from 8 months (only one) to 14 years: Among these 16 subjects who married second time, 7 were normospermic, 6 oligospermic 2 necrospermic and one azoospermic.

In the Bangladesh studies $10.60 \%$ (Muazzam, 1962) and $13.07 \%$ (Muazzam. 1965) indulged in second marriage (none more than one) after 3 to 26 years. This figure is comparable to the figure obtained in Libya, though in general polygamy is commoner in Libya.

This low percentage of second marriage among the sterility cases is no doubt interesting. Inspite of very high rate of illiteracy, general ignorance about defects in male a possible cause of primary sterility and the social acceptance of polygamy in both the Islamic countries of Bangladesh and Libya, such a low incidence of second marriage among the cases of primary sterility indicate that the institution of polygamy is not much misused in these countries. 


\begin{tabular}{lccc}
\hline $\begin{array}{l}\text { Duration of } \\
\text { marriage }\end{array}$ & $\begin{array}{c}\text { Number of } \\
\text { Subjects }\end{array}$ & Percentage & Remarks \\
\hline Less than 1 year & 9 & 5.63 \\
One year & 18 & 11.25 \\
$1 \frac{1}{2^{*}}-\quad 5$ years & 111 & 69.38 \\
$52^{\frac{1}{-}}-10$ years & 18 & 11.25 \\
$11--15$ years & 2 & 1.25 \\
$16--20$ years & 1 & 0.62 \\
$21--25$ years & 1 & 0.62 & \\
\hline Total & 160 & 100.00
\end{tabular}

Table-8. Duration of marriage after which the subjects reported for the investigation of sterility.

\section{Summery}

160 male subjects of primary sterility were investigated in Tripoli, Libya. By routine semen analysis it was found that $37.50 \%(60)$ were normospermic, $37.50 \%(60)$ were Oligospermic, $7.50 \%$ (12) were necrospermic and $17.50 \%$ (28) were azoospermic. $62.50 \%(100)$ subjects had abnormal findings and $25.0 \%$ (40) showed definite cause of non-fecundity. $46.87 \%$ (75) reported for investigation within 2 years of marriage and $86.26 \%(138)$ reported within 5 years. Polygamy due to sterity was very low, only $10 \%$ (16) married second wife.

\section{References}

1. American Fertility Society (1971). How to organise a basic study of the infertile couple, Am. Fert. Soc. Birmingham, U.S.A.

2. Clayton, S. G.. Lewis. T.L.T., and Pinker, G. (1980). Gynaecology by Ten Teachers, 13th edn. Edward Arnold. London.

3. Copenhaver, W.M., Bunge. R. P., and Bunge, M:B. (1971). Bailey's Textbook of Histology, 16 th edn. P. 579, Williams and Wilkins, Baltimore, U.S.A.

4. EL Kassaby, S.M., Muazzam, M.G.. Chist1, R.P., EL Muntasser, I.A., EL Badrl, A.A., and Alloba, I.A. (1984). A study of Endometrial curettage in the Socielist Peoples Libyan Arab Jamahiriya, J. Bangladesh college phys. \& surgeons, vol. I, No 2, P. 6-17.

5. Farris, E.J. (1950). Human Fertility and Problems of Male, The Author's Press.

6. Harrison, R.G. and de-Boar, C.H. (1977). Textbook of Obstetrics and Gynaecology, pp. 27-29, Academic press, London.

7. Hudson, B., Baker, H.W.G., and Krester, D.M. (1980). The abnormal semen sample in infertile couple edited by, Pepperel et al. (1980), 1st edn. P. 84., Churchill Livingstone, London.

8. MacLeod, J. and Gold, R.Z. (1951). The male factor in fertlity and infertility, Sperm Morphology in fertlle and infertile marriage, Fertility and sterility, 2, 39. 
9. MacLeod, J. and Gold, R.Z. (1953). The male factor in fertllity and infertility, Semen quality and certain other factors in relation to ease of conception, Fertility and Sterility, 4, 10.

10. Muazzam, M.G. (1962). Responsibility of Males in Primary Sterility, Medical Digest, India, 30, 531 .

11. Muazzam. M.G. (1965). Investigation of Infertility - Semen Analysis, J. Pak. Med. Assoc. East zone (Now Bangladesh), Khulna Br. Vol. 3, No 1-2, P. 1-5.

12. Muazzam,M.G and EL-kassaby (1983): A study of Infertility in females by Histopathological Examination of Endometrial curettage in Socialist People's Libyan Arab Jamahiriya, Bangladesh medical Journal, 12 (3):101-111.

13. Nelson, C.M.K., and Beng, R.G. (1974). Fertility and Sterility, 25, 503.

"Mothers shall suckle their children for two whole years ...." -Al guran 2:233

Though Al-Qur'an advocated mothers milk for children upto two years, the modern world for centuries preferred bottle feed. It is however a correct realisation of the modern west that mother's milk is the best. The realisation of Qur'anic truth though late is commendable. 